\title{
Contribution of Environmental Factors to Quality Education Delivery in Public Junior High Schools in Talensi-Nabdam District
}

\author{
Ronald A. F. Donbeinaa ${ }^{1}$ Doreen Ahwireng ${ }^{2 *}$ \\ 1.Gbewaa College of Education, Pusiga P. O. Box 157 Pusiga-Bawku Department of Education \\ 2.Department of Educational Studies and Leadership, University of Ghana P. O. Box 1181, Legon, Accra-Ghana
}

\begin{abstract}
This study investigates the contribution of environmental factors to quality education delivery in public Junior High School in Talensi-Nabdam district. Quantitative approach using descriptive survey design was adopted for the study. All 32 headmasters and 230 teachers of the 32 public Junior High Schools in the Talensi-Nabdam district, all the supervisors for the 8 circuits, the District Director of education (DDE), 32 Parent-Teacher Associations (PTAs) and 32 School Management Committees (SMCs), and the District Chief Executive (DCE) of TalensiNabdam totaling 303 participants were randomly selected. Results of the study showed that parents engaged in dressmaking and tailoring, shea butter extraction, pito brewing, pottery, dry season gardening, animal husbandry there are available income generating activities within the communities that parents often engage in for a living. Also, findings revealed that parents used income they generate to support quality education delivery by buying their school uniform for their children, provide exercise books and other writing materials, provide pocket money to their children for school, pay for mock examinations, pay for registration fee for final examinations, and other special levies that a school's PTA may ask for.
\end{abstract}

Keywords: Talensi-Nabdam, district, quality education delivery, shea butter extraction

DOI: $10.7176 / \mathrm{JEP} / 12-2-05$

Publication date: January $31^{\text {st }} 2021$

\section{Introduction}

Over the last two decades has been battling improving quality education delivery at the primary and junior high schools (Casely-Hayford, 2000). A huge amount of Ghana's GDP (10-12\%) is spent on education delivery, however, studies have shown that the education outcomes and learning outcomes among children at the basic level remains low (MOE, 2012; Casely-Hayford, 2011). Despite significant donor contributions to the sector (over 3 billion USD as of 2010), the quality of basic education for the vast majority of Ghana's rural poor remains substandard (Korboe et al., 2010; Casely-Hayford, 2000). The search for quality education delivery at the basic education level seems to be putting more frustrations on the faces of both researchers and the government of Ghana. Despite the provision of classrooms, training and retraining of teachers, and the provision of teaching and learning materials, Ghana's education delivery at the basic schools especially at the junior high schools still lacks the expected quality (The Mitchell Group, 2009; Casely-Hayford, 2000). Ankomah, Koomson, Bosu and Oduro (2005) observed that, successive governments in Ghana have sought and continued to seek strategies for quality delivery of education. Ballantine (1989) posited that educational systems have environments which give them purpose and meaning and define their functions and limitations. Institutional environments of schools such as the family, religion, politics, legal system, economics, and communities show an interrelation of environmental units that form a background to education delivery. Consequently, Epstein (2001) posits that there should be a between the school and the community to help students succeed in school. Healthy school and community relations helps school authorities to understand the social, economic, and cultural ideals of the society which will guide the school to train the youth to live acceptable lives (Epstein, 2001). School is charged with the responsibility of teaching and transmitting the cultural values of the society to the youth. Epstein and Sanders (2002) concur that when schools accept to be influenced by the community then, the school can in turn influence the community by identifying and modifying educationally unacceptable socio-economic activities.

The economic environment in Talensi-Nabdam seems to hold some potential for sustaining quality education delivery. These economic environments include factories such as the Pwalugu Tomato Factory, the cotton ginnery Pusunamongo, and dams. However, there appears to be a disconnect between how these activities contribute to quality delivery of education in the Talensi-Nabdam district. Past researchers have focused on pupils' performance, teacher performance, school supervision, and leadership styles of headteachers. However, there is limited research on environmental components which have potential to contribute to quality education delivery in the TalensiNabdam district. Consequently, this study seeks to investigate contributions of socio-economic environments to the delivery of quality education. This study was intended to investigate in broad terms the socio-economic opportunities that can be used as environmental components to enhance the delivery of quality education in public Junior High School in the Talensi-Nabdam district. Based on the purpose of the study the following question 
guided the study: How do socio-economic activities of the people of Talensi-Nabdam contribute to quality education delivery in public junior high schools?

\section{Literature Review}

The World Bank Policy Study report (as cited in Amedahe, 2007) states that educational quality encompasses how well the education system does the job of accommodating modern market-oriented skills to traditional home-based values and needs. This means how well students acquire knowledge, skills, competencies, and relevant attitudes to enable them cope with societal needs.

Quality education delivery has not been clear in the objectives of Ghana's educational reforms until the 1987 reforms which implemented the junior high school program (Abaidoo, 1993). The 1987 educational reforms had among its objectives, to improving quality, efficiency, and relevance of education (Abaidoo, 1993). Sekyere (2004) states that the Free Compulsory Universal Basic Education (fCUBE) had among its objectives, to improving quality teaching and learning; particularly, in the public basic schools thereby reducing the poor performance of pupils. The strategy for achieving this objective was through curriculum reviews and improved teacher pupil instructional contact time. Aglobitse (2006) asserts that since independence, there have been many attempts to review and reform the education system in Ghana to become more relevant in training human capital needed for effective participation in the process of wealth creation, and economic development. The reform had among its objectives, to improve quality, efficiency, and relevance of education. Since this attention was drawn, efforts are being made by successive governments and stakeholders to give education a new meaning. Efforts include the provision of learning materials, expanding infrastructure, improving teacher quality.

In Ghana key policy documents promulgated and adopted that addressed education for all include the 1992 Constitution, the New Education Reforms adopted in 2007 and the Education Strategic plans (I \&II). Provisions in these policy documents are integrated in the Ghana Poverty Reduction Strategies (GPRS, I \& II) which is the blueprint for national and socio-economic development, (GNECC, 2010; Sekyere, 2010; Osei, Owusu, Asem \& Afutu-Kotey, 2009).

The Ministry of Education and Sports' capitation grant scheme introduced at the beginning of the 2005/2006 academic year for all Public Basic Schools was aimed at removing one main problem that deter particularly the poorest parents from sending their children to school (Sekyere, 2010). This problem is the payment of levies that many Districts charge as means of raising funds to run their schools. Such funds are mainly for school repairs, cultural and sporting activities, even though under the fCUBE program basic education is supposed to be free (Sekyere, 2010; Osei, et al, 2009). The abolishing of payment of fees was aimed at empowering the schools to effectively use the capitation grant to plan and carry out quality improvement activities by use of the School Performance Improvement Plan (SPIP).

Since 1987, the Ministry of Education (MOE) and the Ghana Education Service (GES) have taken measures to address the identified constraints of quality basic education (GES, 2002). The measures include the construction of over 13,000 classrooms in educationally disadvantaged communities and the provision of over 2,100 headteacher houses to attract teachers to handle schools in remote areas and the supply of large quantities of textbooks and stationery to primary schools under the USAID-funded Primary Education Program (PREP). Also, all initial teacher training colleges were upgraded to post-secondary status and the payment of allowances to teacher trainees introduced to attract more qualified candidates into the teaching profession; In line with this, inservice training programs are organized on continuing basis for all trained teachers to upgrade their skills in teaching methodology. The GES (2002) added that management and supervision have been strengthened through upgrading of the district education office to a directorate and the provision of means of transport to facilitate the supervision of schools. Though it was expected that the combined effect of the above measures would be a substantial improvement in learning outcomes at the basic education level, the GES notes that studies proved the measures made little impact on learning outcomes.

The Government of Ghana (GOG) in 2004 came out with a White Paper on Education Reforms which outlines reforms and objectives spanning the entire education sector (GOG, 2004). This catalogue of reforms and objectives were to be implemented from 2007 and the major targets identified to be realized in 2015 and 2020. The White Paper on Education Reform had two key objectives. First it built on the commitments of the ESP for 2003 - 2015 and to ensure that high quality education was provided to children at the basic level. Secondly, it aimed at ensuring that all second cycle education was made more inclusive and appropriate to the needs of young people and the demands of the Ghanaian economy MOESS (as cited in Osei, et al. 2009).

The Anamoah-Mensah committee (2002) explains that, quality of education involves the provision of quality inputs, quality delivery process and quality output, among others. It noted that efforts made by the Ghana Education Service (GES) with support from development partners to improve education quality at the basic level include:

1. The Whole School Development Program (WSD) projects supported by DFID to bring about improvement in all areas of education 
2. Quality Improvement in Primary Schools (QUIPs) supported by USAID, to assist in developing, demonstrating, and replicating processes required to improve schools as part of the WSD.

3. Establishment of District Education Planning Teams (DEPTs) in all the districts to strengthen the capacity of the districts to plan, implement, monitor, and evaluate education improvement programs, among others.

MOWAC/UNICEF (2009) reports that the government of Ghana in 2003 initiated sweeping reforms in the Education Strategic Plan (ESP) for the period 2003-2015. This plan followed a study of the entire system (Education Sector Review of 2002). The ESP initiated 10 key goals which among others were to increase access to and participation in education and training; improve the quality of teaching and learning for enhanced pupils/student achievement; and improve the quality and relevance of academic programmes.

Cobbold, Ghartey, Mensah \&Ocansey (2009) in their research on education in Africa with specific reference to Ghana, agreed that the concept of education quality and its indicators are contested issues, because quality is both quantitative and qualitative. Cobbold, et al (2009) cited World Bank (2004) findings from an impact evaluation of the Bank's support to Basic education in Ghana, revealed that over the period of 1988-2003, the Bank provided 8,000 classroom blocks and 35 million textbooks.

The Mitchell Group (2009) reports that Ghana's education sector strategies have tried in the past to provide basic education for all free of private cost, concentrated assistance on increasing access in deprived districts, shifted emphasis from hardware (school construction) to software (improvements to teacher training, learning materials, and classroom management) and emphasized aid to specific populations known to be underserved and rural. The report indicates that USAID for instance have helped to support projects on Quality Improvement in Primary Schools (QUIPS); Basic Education Comprehensive Assessment System (BECAS); National Literacy Acceleration Program (NALAP) and The Grants and Reporting Accountability to Improve Trust (GAIT).

These support initiatives led to increased Gross Enrolment rates in junior high schools from $73 \%-77 \%$ between 2003 and 2006. The completion rate in junior high school was $65 \%$ by the close of 2009 . These are significant accomplishments in relation to the $2003-2015$ Education Sector Plan. The Group expressed concern however, that the increases did not match achievements. This implies there is need to find possible ways of improving performance. This is a challenge for parents, teachers, government and all other stakeholders of education and there is the need for collaboration. "To ensure effective teaching and learning in pre-tertiary institutions, the Inspectorate Division of the GES has introduced a Participatory Performance Monitoring System (PPMS) in basic schools" (GES, 2002, p. 48)

The Ministry of Education, Science and Sports [MOESS] (2008) states that the effects of household wealth on educational attainment have been investigated in the population cohort aged 15 to 19 years using three Core Welfare Indicators Survey in Quintiles (CWIQ). According to the report, findings of the CWIQ suggest that children attain different levels of education across different wealth groupings particularly when looking at the basic education sector. For instance, out of the 65 per cent of children who completed primary 1 from the poor wealth grouping only 14 per cent completed JSS 3 . Out of the 96 per cent of children from the affluent wealth grouping who completed P1, a much higher proportion completed JSS3 (55 percent). The educational attainment profile across various regions reveals that children in the higher wealth quintiles are more likely to complete primary and JSS schooling compared to their lower wealth quintile counterparts (MOESS, 2008).

Children from households in the lowest welfare quintile have significantly lower net primary and junior high enrolment and attendance rates compared to children living in households with higher welfare measures. Children from households in the lower quintile are likely to enter primary school at an older age compared with children from households in higher welfare quintiles, and more likely to drop out of school (MOESS, 2008).

MOESS (2008) further indicates that the difference in enrolment between wealthy and poor households increases at higher levels of education. At the JHS level, this could be because of the opportunity cost associated with sending a child to school even though there are no school fees and the presence of the capitation grant. The demand for education will be less for low-income families in rural areas because of both the opportunity cost, and that the cost to poorer households also represents a greater proportion of household income. When there is no benefit seen to education, parents would rather the child work than spend money on uniforms and transport to school. Thus, the need remains to investigate and support districts that are falling behind, as well as social and economic groups that continue to be excluded or at risk of exclusion.

Akumbuno (2006) found that absenteeism, irregular attendance, and poor academic work of basic school children in the Techiman Municipality were strongly due to poor socio-economic backgrounds and peer group pressure. According to Akumbuno (2006), most basic school children (including JHS students) engage themselves in economic activities on the market days and during harvesting and Christmas periods when they could reap much profit. It was further found that most students from low socio-economic families in Techiman sometimes, must stay away from school to work to pay their school fees and provide themselves with their educational needs and pocket money.

Akumbuno's (2006) research is consistent with Agezo and Christian (2002), that most parents in and around 
Elmina consider their children as economic assets. Parents and guardians employ the services of their children in fishing at the expense of their school.

Obeng (2005) espoused that the level of household income accounts for the level of enrolments into schools because, when parents realize the benefits that accrue to the family because a child's education outweighs the cost, they tend to enroll their wards in school. Obeng (2005) further argued, that socio-economic status can be reassured in different ways and whatever the measure is; socio-economic status is positively correlated with factors which affect pupils' attendance at basic school education. The higher a student's socio-economic background the greater his or her educational accomplishment and attainment are likely to be.

On the contrary, Adams and Bjork as cited in Obeng (2005) contended that, because parental attitude is a function of household income, it has been found that when household income is low vis-à-vis the cost of schooling, economically handicapped households prefer spending on the child whom they are optimistic of reaping great and quick benefits.

Etsey (2007) argues the provision of basic school needs such as school uniforms, school bags, exercise books pens pencils and rulers as home variables and a responsibility of parents in contributing to students' performance. Etsey (2007) found that less than $50 \%$ of the pupils in the Shama sub - metro schools had these basic needs provided. The result from lack of these basic school needs was low academic performance.

As cited in MOWAC/UNICEF (2009), a study by the Department of Social Works of the University of Ghana on child labour migration from the upper East Region into cocoa-growing areas confirmed reports, that, children between the ages of 12 and 17 migrate to work in cocoa farms in Ghana's middle belt. According to the report, over 70 per cent of these children had either stopped school or had never been to school. The report indicates that a rise in family incomes will help curb the child labour.

To remedy this socio-economic situation in the cocoa growing areas of Ghana, the MOWAC/UNICEF (2009) explained that, the ministry of Manpower, Youth and Employment (MMYE) in collaboration with ILO, UNICEF, Cocoa Board (COCOBOD) and other stakeholders in the cocoa sub-sector formulated a national framework known as the National Cocoa Child Labour Elimination Program -2006-2011 (NCCLEP), to guide all actions to ensure the elimination of child labour by 2011. Ministry of Education, Science and Sports [MOESS] (2008) states that there are many sources of financing for basic education. The Government of Ghana provides the largest proportion of spending on basic education. Other sources include donor funds, HIPC funds, the District Assembly Common Fund (DACF), and the Ghana Education Trust Fund (GETFund).

Government of Ghana $(\mathrm{GoG})$ share of the total education resource envelope is falling. In 2004 it accounted for $68 \%$ of the budget, in $200566 \%$ and in $200661 \%$. If the GoG budget is the primary source of funding for basic education and its share is falling, it raises potentially serious concerns about the future financing of basic education, as well as the efficiency in spending at this level.

There is an exploration of the education environment in a more technological dimension that cannot be achieved by any nation without much cost. As time passed, technology advances and the world has become a global village and more educational environments are being discovered.

\section{Methodology}

\subsection{Research Site}

The study was conducted in the Talensi-Nabdam district of the upper east region of Ghana.

Talensi-Nabdam district was carved from the Bolgatanga District with Tongo as its capital. It is bordered to the north by the Bolgatanga District, to the south by the West and East Mamprusi Districts, and the east by the Bawku West District. The district is made up of mostly rural communities. The inhabitants engage small scale economic activities which include dry season gardening, shea butter extraction and "galamsey" which is partly used in taking care of their wards' education.

\subsection{Research Design}

This quantitative study adopted descriptive survey design. The descriptive survey design was used in this study to find out the socio-economic activities that reflect the aspects of traditional contexts in which the people of TalensiNabdam are educated. This was to enable me make inferences and conclusions on the contributions of such activities to quality education delivery in public junior high schools in the area. Avoke (2005) explained that descriptive surveys are designs that portray accurately the characteristics of individuals, situations, or events. The Colorado State University (2012) stated that, though surveys are relatively expensive, they are useful in describing the characteristics of a large population. Many questions can be asked about a given topic giving considerable flexibility to the analysis. This design is therefore useful in this study considering the sample involved and the large number of questions to be answered.

\subsection{Population}

The target population for this study included all 32 headmasters and 230 teachers of the 32 public Junior High 
Schools in the Talensi-Nabdam district. It also included all the supervisors for the 8 circuits, the District Director of education (DDE), 32 Parent-Teacher Associations (PTAs) and 32 School Management Committees (SMCs), and the District Chief Executive (DCE) of Talensi-Nabdam totaling 303 research participants.

\subsection{Sample and Sampling Procedure}

A total of 13 schools were selected from 28 schools through the simple random sampling technique on circuit basis (Creswell, 2014; Johnson and Christensen, 2012) to ensure that all circuits had independent chance of being selected. Four schools from two circuits were initially selected through the same technique for pilot-testing and schools from those circuits were not included in the main data. From each sampled school the stratified sampling technique was adopted to select respondents to answer the questionnaires. Respondents included the headmasters, teachers, SMC and PTA executives and parents from the selected schools. Respondents were divided into two categories. The school heads and teachers constituted one category selected to represent the school. The second category comprised the SMC and PTA executives and parents representing the community.

Agyedu, Donkor and Obeng (2007) assert that in purposive sampling the sample is chosen to suit the purpose of the study. Three teachers were also selected through the simple random sampling procedure from each sampled school. Two parents were conveniently sampled with the help of the headmasters/headmistresses of the schools sampled. This resulted in a total of 13 respondents from each of the 13 schools sampled. All the 8 circuit supervisors, the DDE and the DCE were part of the sample. Consequently, a total of 179 respondents participated in the study.

Table 1: Composition of Estimated Population and Sample Size

\begin{tabular}{|c|c|c|c|c|}
\hline \multicolumn{2}{|c|}{ Category } & \multirow{2}{*}{$\begin{array}{l}\text { Estimated Population } \\
208\end{array}$} & \multirow{2}{*}{$\begin{array}{l}\text { Sample } \\
\text { Size } \\
117\end{array}$} & \multirow{2}{*}{$\begin{array}{l}\text { Number Responded } \\
106\end{array}$} \\
\hline A. & SMCs and PTAs & & & \\
\hline B. & Heads/Teachers & 109 & 52 & 51 \\
\hline C. & $\mathrm{C} / \mathrm{S}$ & 8 & 8 & 8 \\
\hline D. & DDE & 1 & 1 & 1 \\
\hline & DCE & 1 & 1 & 1 \\
\hline \multicolumn{2}{|c|}{ Total } & 327 & 179 & 167 \\
\hline
\end{tabular}

Key:

SMC- School Management Committee

PTA- Parent-Teacher Association

C/S- Circuit Supervisor

DDE- District Director of Education

DCE- District Chief Executive

Table 2: Composition of Respondents by Gender

\begin{tabular}{lllllllllllll}
\hline Gender & \multicolumn{2}{l}{ SMC/PTA/ } & \multicolumn{2}{l}{ Heads/ } & \multicolumn{2}{l}{ C/S } & \multicolumn{2}{c}{ DDE } & \multicolumn{2}{c}{ DCE } & \multicolumn{3}{c}{ Total } \\
& \multicolumn{2}{l}{ Parents } & \multicolumn{2}{l}{ Teachers } & & & & & & & & \\
& F & $\%$ & F & $\%$ & F & $\%$ & F & $\%$ & F & $\%$ & F & $\%$ \\
\hline Male & 81 & 76.4 & 41 & 80.4 & 7 & 87.5 & 1 & 100.0 & 0 & 00.0 & 130 & 77.8 \\
Female & 25 & 23.6 & 10 & 19.6 & 1 & 12.5 & 0 & 00.0 & 1 & 100.0 & 37 & 22.2 \\
\hline Total & $\mathbf{1 0 6}$ & $\mathbf{1 0 0 . 0}$ & $\mathbf{5 1}$ & $\mathbf{1 0 0 . 0}$ & $\mathbf{8}$ & $\mathbf{1 0 0 . 0}$ & $\mathbf{1}$ & $\mathbf{1 0 0 . 0}$ & $\mathbf{1}$ & $\mathbf{0 0 . 0}$ & $\mathbf{1 6 7}$ & $\mathbf{1 0 0 . 0}$ \\
\hline
\end{tabular}

$\mathrm{F}=$ Frequency

\subsection{Research Instruments}

Questionnaire was used to elicit information from the Headmaster, Teachers, SMCs, and PTA executives.

A total of 68 items were developed from three themes and were used to seek information to answer the research question. The questionnaires were divided into five parts. The first part asked for information on the personal background of the respondents. Part IV comprised information on available income-generating activities engaged in by communities and ways in which the generated income is used to support quality education delivery in public junior high schools. Finally, part $\mathrm{V}$ was used to find out what the district education directorate and the district assembly were doing with socio-economic environments for enhanced quality education delivery.

A total of 26 items were developed and used to seek information that answered the research question. The questionnaires were divided into three parts. The first part asked for information on the personal background of the respondents. Part two, comprised information on available income-generating activities engaged in by communities and ways in which the generated income is used to support quality education delivery in public junior high schools. Finally, part three was used to find out what the district education directorate and the district assembly were doing with socio-economic environments for enhanced quality education delivery. 


\subsubsection{Pilot-Testing of Instruments}

Four junior high schools within the district were initially selected from two circuits through simple random sampling technique to pilot-test the questionnaire instrument. Four schools were selected because they are within the district and have similar socio-economic characteristics with the main sample selected. Moreover, TalensiNabdam district has its peculiarities in terms of cultural and economic activities. Therefore, pilot-testing the instrument in a different environment could give false impression about the reliability of the instrument. The pilottest was to help remove improperly framed questions and unclear choice of responses that might appear in the items. Additionally, pilot-test was used to ensure reliability of the questionnaire sampling and data collection procedures. The instrument was administered to the SMC, PTA, parents, headmaster/headmistress and teachers. The Cronbach's Alpha reliability test yielded .800 and .868 for the SMC, PTA, and parent, respectively.

3.4.2 Validity of Instruments

Pilot-test was used as a measure to ensure the validity of the instrument. Comments made by respondents on omissions and all other ambiguities such as unclear responses were duly removed before administering the instrument.

\subsubsection{Reliability}

The instruments developed were subjected to scrutiny by my colleagues for expert advice and professional consideration. The questionnaire was tested on $16 \mathrm{JHS}$ heads and teachers and $36 \mathrm{SMC}$, PTA, and parent. The Cronbach's Alpha reliability co-efficient of .868 and .800 were obtained for the two groups, respectively.

3.4.4. Data Collection Procedure

Direct contacts were made to seek consent of respondents for data collection. Questionnaires were given to heads and teachers of each of the sampled schools. The answered questionnaires were retrieved the next day. Arrangements were made through heads of the sampled schools to meet parents who could neither read nor write in English with a volunteered teacher who guided them to answer the questionnaires.

\section{Data Analysis}

Quantitative data were analyzed with the use of frequency counts and percentages. The responses were sorted, scored, coded and analysed using the Statistical Package for the Social Sciences (SPSS) windows 16.0 software package. The questionnaires were analysed on an item by item basis using numerical values and this yielded quantitative data which was computed into frequencies and percentages and presented in tables for interpretation. A scoring key was developed for the various responses to the questionnaire items. The various options provided in the questionnaire were assigned numerical values beginning from $1-4$ or $1-3$, depending on the options available for the respondents to choose from. The responses made were therefore represented with the coded numerical values and the data processed using the SPSS windows 16.0 software package.

\subsection{Results}

The purpose of this study was to find out how the socio-economic activities of the people of Talensi-Nabdam district are being used as environmental factors to contribute to quality education delivery in public junior high schools. Questionnaire was used for data collection.

Table 3: SMC, PTA and Parent Respondents who returned their completed Questionnaire

\begin{tabular}{llll}
\hline Group & Sample & Frequency & Percentage \\
\hline PTA Chairperson & 13 & 13 & 11 \\
PTA Treasurer & 13 & 11 & 9 \\
PTA Secretary & 13 & 13 & 11 \\
SMC Chairperson & 13 & 12 & 10 \\
SMC Chief's Representative & 13 & 11 & 9 \\
Unit Committee Member & 13 & 11 & 9 \\
Assembly Member & 13 & 11 & 9 \\
Parent & 26 & 24 & 21 \\
\hline Total & $\mathbf{1 1 7}$ & $\mathbf{1 0 6}$ & $\mathbf{8 9}$ \\
\hline
\end{tabular}

In Table 3, only the PTA chairpersons and PTA secretaries from the thirteen schools selected responded and returned their questionnaire, one of the SMC chairpersons did not respond. Also, two members each from the rest of the groups did not respond. 
Table 4: Educational Background of SMC, PTA, and Parent Respondents

\begin{tabular}{lll}
\hline Level attained & Frequency & Percentage \\
\hline Never been to school & 26 & 24.5 \\
Basic & 27 & 25.5 \\
Secondary & 19 & 17.9 \\
Post-Secondary & 22 & 20.8 \\
Other (specify) & 12 & 11.3 \\
\hline Total & $\mathbf{1 0 6}$ & $\mathbf{1 0 0 . 0}$ \\
\hline
\end{tabular}

It is indicated in Table 4 that out of the 106 respondents in this category, 26(24.5\%) have never been to school which suggest a high illiteracy rate in the district. 27(25.5\%) respondents indicated they had basic education. This includes those who had education at the primary, middle school, or junior high level.11.3\% showed they attained other levels of education. The explanation is that the 12 respondents had education in the vocational and technical institutions, Polytechnics, or other tertiary institutions.

Table 5: Classification of Headmaster/Headmistress and Teacher Respondents

\begin{tabular}{lll}
\hline Position held & Frequency & Percentage \\
\hline Headmaster/mistress & 12 & 23.5 \\
Teacher & 39 & 76.5 \\
\hline Total & $\mathbf{5 1}$ & $\mathbf{1 0 0 . 0}$ \\
\hline
\end{tabular}

51 out of the 52 respondents in this category were able to answer and return the questionnaires.

Table 6: Professional Qualification of Headmasters/Mistresses and Teachers

\begin{tabular}{lll}
\hline Qualification & Frequency & Percentage \\
\hline Untrained & 11 & 21.6 \\
Teachers' Cert. 'A' (Post middle) & 2 & 3.9 \\
Teachers' Cert. 'A'(Post-Secondary) & 11 & 21.6 \\
Teachers' Cert. (Diploma) & 22 & 43.1 \\
Specialist teachers' Cert. & 1 & 2.0 \\
Other Certs. & 4 & 7.8 \\
\hline Total & $\mathbf{5 1}$ & $\mathbf{1 0 0 . 0}$ \\
\hline
\end{tabular}

Research Question: How do economic activities of the people of Talensi-Nabdam contribute to quality education delivery in public junior high schools?

Information was sought from respondents on the contributions of the socio-economic environment to the delivery of quality education in public junior high schools in Talensi-Nabdam district. First information was sought that identified income-generating activities that parents in the district often engaged in, to raise funds to support their children's education were sought. Second, information on how the income generated is used to support quality education delivery was sought. The results are presented in Tables 13 and 14. 
Table 13: Income-Generating Activities Parents used in Supporting their

Children's Education in Junior High Schools

\begin{tabular}{|c|c|c|c|c|}
\hline \multirow{2}{*}{$\begin{array}{l}\text { Income - generating } \\
\text { activity }\end{array}$} & \multirow[t]{2}{*}{ Respondent } & \multicolumn{3}{|l|}{ Responses } \\
\hline & & $\begin{array}{l}\text { Do not engage } \\
\text { in } \\
\text { Freq. }(\%)\end{array}$ & $\begin{array}{l}\text { Occasionally } \\
\text { engage in freq. } \\
(\%)\end{array}$ & $\begin{array}{l}\text { Often engage } \\
\text { in } \\
\text { Freq. }(\%)\end{array}$ \\
\hline $\begin{array}{l}\text { Dressmaking and } \\
\text { tailoring }\end{array}$ & $\begin{array}{l}\text { SMCs/PTAs/Parents } \\
\text { Headmasters/Teachers }\end{array}$ & $\begin{array}{l}33(31.1) \\
18(35.3)\end{array}$ & $\begin{array}{l}39(36.8) \\
24(47.1)\end{array}$ & $\begin{array}{l}34(32,1) \\
9(17.6)\end{array}$ \\
\hline Soap making & $\begin{array}{l}\text { SMCs/PTAs /Parents } \\
\text { Headmasters/Teachers }\end{array}$ & $\begin{array}{l}59(56.2) \\
38(74.5)\end{array}$ & $\begin{array}{l}43(41.0) \\
8(15.7)\end{array}$ & $\begin{array}{l}3(2.9) \\
5(9.8)\end{array}$ \\
\hline $\begin{array}{ll}\text { Shea } & \text { butter } \\
\text { extraction } & \end{array}$ & $\begin{array}{l}\text { SMCs/PTAs/Parents } \\
\text { Headmasters/Teachers }\end{array}$ & $\begin{array}{l}5(4.7) \\
3(5.9)\end{array}$ & $\begin{array}{l}31(29.2) \\
19(37.3)\end{array}$ & $\begin{array}{l}70(66.0) \\
29(56.9)\end{array}$ \\
\hline Pito brewing & $\begin{array}{l}\text { SMCs/PTAs /Parents } \\
\text { Headmasters/Teachers }\end{array}$ & $\begin{array}{l}11(10.4) \\
5(9.8)\end{array}$ & $\begin{array}{l}34(32.1) \\
13(25.5)\end{array}$ & $\begin{array}{l}61(57.5) \\
33(64.7)\end{array}$ \\
\hline Illegal mining & $\begin{array}{l}\text { SMCs/PTAs/Parents } \\
\text { Headmasters/Teachers }\end{array}$ & $\begin{array}{l}41(38.7) \\
20(40.0)\end{array}$ & $\begin{array}{l}40(37.7) \\
17(34.0)\end{array}$ & $\begin{array}{l}25(23.6) \\
13(26.0)\end{array}$ \\
\hline Pottery & $\begin{array}{l}\text { SMCs/PTAs/Parents } \\
\text { Headmasters/Teachers }\end{array}$ & $\begin{array}{l}26(24.5) \\
12(23.5)\end{array}$ & $\begin{array}{l}23(21.7) \\
12(23.5)\end{array}$ & $\begin{array}{l}57(53.8) \\
27(52.9)\end{array}$ \\
\hline Dry season & $\begin{array}{l}\text { SMCs/PTAs/Parents } \\
\text { Headmasters/Teachers }\end{array}$ & $\begin{array}{l}76(71.7) \\
33(64.7)\end{array}$ & $\begin{array}{l}18(17.0) \\
11(21.6)\end{array}$ & $\begin{array}{l}10(9.4) \\
7(13.7)\end{array}$ \\
\hline $\begin{array}{l}\text { Basket, Hat and } \\
\text { Cloth weaving }\end{array}$ & $\begin{array}{l}\text { SMCs/PTAs/Parents } \\
\text { Headmasters/Teachers }\end{array}$ & $\begin{array}{l}18(17.0) \\
13(25.5)\end{array}$ & $\begin{array}{l}51(48.1) \\
28(54.9)\end{array}$ & $\begin{array}{l}36(34.0) \\
10(19.2)\end{array}$ \\
\hline $\begin{array}{l}\text { Animal } \\
\text { husbandry }\end{array}$ & $\begin{array}{l}\text { SMCs/PTAs /Parents } \\
\text { Headmasters/Teachers }\end{array}$ & $\begin{array}{l}46(43.4) \\
26(51.0)\end{array}$ & $\begin{array}{l}43(40.6) \\
13(25.5)\end{array}$ & $\begin{array}{l}16(15.1) \\
12(23.5)\end{array}$ \\
\hline Food vending & $\begin{array}{l}\text { SMCs/PTAs/Parents } \\
\text { Headmasters/Teachers }\end{array}$ & $\begin{array}{l}10(9.4) \\
13(25.5)\end{array}$ & $\begin{array}{l}22(20.8) \\
13(25.5)\end{array}$ & $\begin{array}{l}73(68.9) \\
24(47.1)\end{array}$ \\
\hline & $\begin{array}{l}\text { SMCs/PTAs/Parents } \\
\text { Headmasters/Teachers }\end{array}$ & $\begin{array}{l}7(6.6) \\
3(3.9)\end{array}$ & $\begin{array}{l}42(39.6) \\
22(43.1)\end{array}$ & $\begin{array}{l}57(53.8) \\
26(51.0)\end{array}$ \\
\hline
\end{tabular}

The results in Table 13 indicate that there are available income generating activities within the communities that parents often engage in for a living. The results showed 51(32.5\%) responses indicate parents do not engage in dressmaking and tailoring to generate income; 63(40.1\%) indicated the activity is occasionally engaged in and $43(27.4 \%)$ responses indicated the activity is often engaged in by parents.

Majority of the responses, $97(61.8 \%$ ) indicated parents do not engage in soap making as an income-generating activity. The results further revealed most of the responses $99(63.1 \%)$ indicated parents often engage in shea butter extraction. Similarly, 94(60.0\%) majority of responses indicated that parents often engage in pito brewing to generate income. Another 47(30.0\%) also indicate that parents engage in pito brewing occasionally.

Also, 61(39.0\%) respondents indicated parents do not engage in charcoal burning and selling to generate income. $57(36.3 \%)$ respondents however, indicated parents occasionally engage in the activity and another $38(24.2 \%)$ showed that parents often engage in charcoal burning and selling activities to generate income. It was further revealed from the results that $38(24.2 \%)$ respondents indicated parents do not engage in illegal mining activities and a majority of $84(53.5 \%)$ respondents mentioned that parents often engage in illegal mining activities. Pottery is another income-generating activity that majority of responses from the results, 109(69.4\%) showed that parents do not engage in. It was also indicated that $79(50.3 \%)$ respondents which is a little over one-half indicated 
parents occasionally engage in dry season gardening. It must be noted that dry season gardening is a seasonal activity, and the indication of this results mean that parents who have access to water bodies during the season do engage in the activity to generate income.

The results in Table 13 further revealed that $72(46.0 \%)$ responses indicated that parents do not engage in basket, hat, and cloth weaving to generate income. Another 56(36.0\%) responses indicated the activity was occasionally engaged in by parents and $28(17.8 \%)$ showed parents often engage in basket, hat, and cloth weaving activity.

Animal husbandry was indicated by $97(61.8 \%)$ responses as an income-generating activity often engaged in by parents in the Talensi-Nabdam district. Results from 35(22.3\%) respondents indicated parents occasionally engage in the activity. Finally, findings in Table 13 showed that $10(6.4 \%)$ of the respondents indicated food vending as an economic activity that parents do not engage in, 64(40.7\%) indicated parents occasionally engage in it and $83(52.9 \%)$ responses indicated parents often engage in food vending to generate income.

Results from the study revealed that every community in the Talensi-Nabdam district has several activities which the people engage in for capital gains. Income is generated from whatever economic activity that people choose to engage in, and part of the gains are used to support the education of children including junior high school students. Income-generating activities available are mostly from primary sources and vary in type from one community to the other. As such, people choose the available and profit yielding ventures to engage in.

Table 14: How Income Generated by Parents is used to Contribute to Quality Education Delivery

\begin{tabular}{|c|c|c|c|c|c|}
\hline \multirow{2}{*}{$\begin{array}{l}\text { Use of income (area } \\
\text { of } \\
\text { support) }\end{array}$} & \multirow[t]{2}{*}{ Respondents } & \multicolumn{4}{|c|}{ Responses } \\
\hline & & $\begin{array}{l}\text { SD } \\
\text { F }(\%)\end{array}$ & $\begin{array}{l}\mathrm{D} \\
\mathrm{F}(\%)\end{array}$ & $\begin{array}{l}\text { A } \\
\text { F }(\%)\end{array}$ & $\begin{array}{l}\text { SA } \\
\text { F (\%) }\end{array}$ \\
\hline $\begin{array}{l}\text { Parents provide } \\
\text { school uniform }\end{array}$ & $\begin{array}{l}\text { SMCs/PTAs/Parents } \\
\text { Headmasters/Teachers }\end{array}$ & $\begin{array}{l}9(8.5) \\
2(3.9)\end{array}$ & $\begin{array}{l}6(5.7) \\
0(0.0)\end{array}$ & $\begin{array}{l}28(26.4) \\
23(45.1)\end{array}$ & $\begin{array}{l}63(59.4) \\
26(51.0)\end{array}$ \\
\hline $\begin{array}{l}\text { Parents provide } \\
\text { exercise } \\
\text { other books and } \\
\text { material } \\
\text { school uniform }\end{array}$ & $\begin{array}{l}\text { SMCs/PTAs/Parents } \\
\text { Headmasters/Teachers }\end{array}$ & $\begin{array}{l}19(17.9) \\
2(3.9)\end{array}$ & $\begin{array}{l}5(4.7) \\
2(3.9)\end{array}$ & $\begin{array}{l}36(34.0) \\
25(49.0)\end{array}$ & $\begin{array}{l}46(43.4) \\
22(43.1)\end{array}$ \\
\hline $\begin{array}{l}\text { Parents provide } \\
\text { supplementary } \\
\text { readers }\end{array}$ & $\begin{array}{l}\text { SMCs/PTAs/Parents } \\
\text { Headmasters/Teachers }\end{array}$ & $\begin{array}{l}24(22.6) \\
8(15.7)\end{array}$ & $\begin{array}{l}46(43.4) \\
22(43.1)\end{array}$ & $\begin{array}{l}44(41.5) \\
19(37.3)\end{array}$ & $\begin{array}{l}13(12.3) \\
3(5.9)\end{array}$ \\
\hline $\begin{array}{l}\text { Parents give pocket } \\
\text { money to their } \\
\text { children attending } \\
\text { junior high school }\end{array}$ & $\begin{array}{l}\text { SMCs/PTAs/Parents } \\
\text { Headmasters/Teachers }\end{array}$ & $\begin{array}{l}4(3.8) \\
5(9.8)\end{array}$ & $\begin{array}{l}7(6.6) \\
9(17.6)\end{array}$ & $\begin{array}{l}61(57.5) \\
29(56.9)\end{array}$ & $\begin{array}{l}34(32.1) \\
8(15.7)\end{array}$ \\
\hline
\end{tabular}

In Table 14 above, the findings revealed that majority of the respondents $140(89.2 \%)$ out of the total 157 agreed that parents use income they generate to buy their children's school uniform. Also, 129(82.2\%) respondents agreed that income generated by parents are used in providing exercise books and other writing materials. $28(17.8 \%)$ respondents disagreed that parents used the income in providing exercise books and other writing materials. The reason is that the distribution of free uniforms and exercise books to basic school children by the government was yet to start in the district. Besides, parents were educated through sensitization programs and traditional social occasions to put in their best to support their children's education. The results further indicated that $78(49.7 \%)$ respondents disagreed that parents use income they generate to provide supplementary readers. Majority $79(50.3 \%)$ of respondents however, agreed that supplementary readers were provided from income generated by parents. Finally, responses from 132(84.1\%) majority agreed that parents give pocket money from income they generate to their children attending junior high school.

The study findings in Table 14 shows that income generated by parents in the Talensi-Nabdam district are partly used to support quality education delivery by providing their wards with school uniforms, exercise books and other writing materials, pay for mock examinations, registration for final examinations among others.

\subsection{Discussion}

The findings of this study revealed there are several income-generating activities available to communities in the district and parents choose to engage themselves in income-generating activities available in their communities 
which can yield optimal profits. These activities include dressmaking/tailoring, shea butter extraction, pito brewing, illegal mining, dry season gardening, animal husbandry, and food vending, among others. Income-generating activities are carried out on individual basis with very meager capital and are meant to provide for the daily needs of families. This finding is consistent with earlier research (Agezo \& Christian, 2002; Akumbuno, 2006)

It is also revealed in this study that income generated by parents is partly used to support quality education delivery. The support provided is in many forms including the provision of school uniforms, exercise books and other writing materials, payment for mock examinations, registration for students' final examinations and other special levies that a school's PTA may ask for. This means it cannot be proudly stated that the fCUBE policy especially the abolishing of fee paying has been successful. This finding therefore agrees with findings made in previous studies (Osei, et al, 2009; Sekyere 2010)

The District Director of Education attends community durbars and other social functions and uses the opportunities to inform chiefs and communities about the progress of junior high schools in the district and encourage them to support schools in providing quality education at the basic level.

\subsection{Implications of the Study}

The implication of the findings is that quality education at the basic level is sustainable in Talensi-Nabdam district because, there are avenues for parents to use in meeting the cost. It also implies that students can be equipped with basic employable skills and this will broaden their knowledge and perception about employment opportunities. It will eventually contribute in no small measure to achieving Ghana's education philosophy of producing "well behaved individuals with the requisite knowledge, skills, values, aptitudes and attitudes to become functional and productive citizens" (Sekyere, 2010, p.86). The implication is that the socio-economic background of JHS students in the district makes the provision of education possible; sustains education delivery and encourages students to complete their basic education program. The findings also brought to light that the government's free school uniform and exercise books distribution has still not reached some schools in the district.

\subsection{Limitations of the Study}

Schools for pilot-testing were selected within the district in which the study was conducted. Consequently, it is possible that some respondents for the pilot-test could have discussed some items in the questionnaire with people who were later used as respondents during the main data collection. Also, parent respondents to the questionnaire were sampled using the convenience sampling procedure instead of random sampling. Views of parents cannot be generalized because of the limited number of respondents attained through convenient sampling. Consequently, future research should investigate the factors militating against the exploration of socio-economic environments to promote quality education delivery in junior high schools in Ghana.

\subsection{Recommendations}

Based on the study's findings it is recommended that chiefs should develop plans for supporting quality education delivery within their respective jurisdictions and make these plans known to school authorities so that they can factor them into the School Improvement Plans (SIPs). Also, students in junior high schools should be allowed to take their textbooks home to enable them study and do their exercises in advance. In addition, parents should be encouraged through the School Performance Appraisal Meeting (SPAM) and other sensitization programs purchase supplementary reading materials for their children in junior high schools. Parents should allow the children some free time to learn at home. Furthermore, the district assembly should create an avenue for making funds available to groups that would like to borrow for their businesses. Finally, the district assembly, the district education directorate and chiefs should continue to collaborate and consult in identifying all socio-economic factors that can contribute to quality education delivery in the district.

\section{Conclusion}

There are locally based economic activities available in the district that parents engage in to generate income. Part of the income is used to provide basic school needs for student. Poverty hinders parents from adequately supporting their children's education. Income generated from the dressmaking/tailoring, shea butter extraction, pito brewing, illegal mining, dry season gardening, animal husbandry, and food vending were partly used to support quality education delivery. The support provided is in many forms including the provision of school uniforms, exercise books and other writing materials, payment for mock examinations, registration for students' final examinations and other special levies that a school's PTA may ask for.

\section{References}

Abaidoo, P. K. (1993), "Brief notes for the higher rank aspirant ( $3^{\text {rd }}$ ed.)", Unpublished monograph

Agezo, C. K., \& Christian, J. (2002), "The impact of economic environment on primary school attendance: A case of Elmina in the Central Region of Ghana", Journal of Educational Management 4, 137-143. 
Aglobitse, P. B. (2006), “Determinants of school attainment and school achievement in Ghana. Unpublished PhD thesis", University of Cape Coast, Cape Coast.

Agyedu, G. O., Donkor, F., \& Obeng, S. (2007), "Research methods”, Unpublished monograph

Akumbuno, A. F. (2006), "Effects of economic activities on academic achievements of basic school children in Techiman”, Unpublished M.Ed. master's dissertation, University of Cape Coast, Cape Coast.

Amedahe, F.K. (2007), "Quality education in Ghana: Ghana's status and challenges in the $21^{\text {st }}$ Century. In D. E. K. Amenumey (Ed), Challenges of education in Ghana in the 21 Century”, (pp.102 - 119). Accra: WOELI PUBLISHING SERVICES

Ankomah, Y. A., Koomson, J. A., Bosu, R. S., \& Oduro, G. T. K. (2005), "Implementing quality education in low income countries (EdQual)", $\quad$ Retrieved January $29, \quad 2011$ from http://www.dfid.gov.uk/r4d/PDF/Outputs/ImpQuality_RPC/ghanarev.pdf

Atakpa, S. K., \& Ankomah, Y.A. (1998), "Baseline study on the state of school management in Ghana", Journal of educational management 1 (1), 1-20.

Avoke, M. (2005), "Special educational needs in Ghana: Policy, practice, and research”, Winneba: Special Educational Books, Department of Special Education.

Ballantine, J.H. (1989), "The sociology of education: A systematic analysis (2 $2^{\text {nd }}$ ed.)", Englewood Cliffs, New Jersey: Prentice-Hall.

Borg, W. R., \& Gall, M. D. (1983), "Educational research: An introduction (4 ${ }^{\text {th }}$ ed.). New York: Longman Inc.

Casely-Hayford, L. (2000), "Education, Culture and Development in Northern Ghana: Micro Realities and Macro Context: Implications for Policy and Practice", University of Sussex: Unpublished PhD thesis. Cobbold, C., Ghartey, J. A., Mensah, F., \& Ocansey, F. (2009), "Research on education in Africa with specific reference to Ghana. In revitalizing higher education in Sub-Saharan Africa", A United Nations University Project Report

Creswell, J.W. (2008), "Educational research: Planning, conducting, and evaluating quantitative and qualitative research”, New Jersey: Pearson Education Inc.

Etsey, Y. K. A. (2007), "The challenge of low academic achievements in rural junior secondary schools in Ghana: The case of Shama sub-metro in the Western Region. In D. E. K. Amenumey (Ed.), Challenges of education in Ghana in the 21 Century, (pp. 120 -153)", Accra: WOELI PUBLISHING SERVICES

GES. (1994), "Head teachers' handbook. Accra", Ghana: Ministry of Education.

GES. (2002), "Circuit Supervisors' handbook", Accra: Ministry of Education http://unesdoc.unesco.org/images/0018/001878/187869e.pdf

IREWOC. (2007), "Deprived children and education in Ghana", Retrieved July 4, 2011 from http://www.childlabour.net/documents/educationproject/Ghana_education_final.pdf

Korboe, D., et al. (2011), "Participatory Poverty and Vulnerability Assessment (PPVA): Understanding the Regional Dynamics of Poverty with particular focus on Northern Ghana. GOG/DFID/UNICEF/World Bank", Accra, Ghana

McWilliam, O. A., \& Kwamina-Poh, M. A. (1975), "The development of education in Ghana", London: Longman Group Limited

MOESS (2008), "Preliminary education sector performance report", Retrieved June 27, 2011 from http://www.gnecc.org/download/Preliminary\%20Education\%20Sector\%20Report\%202008.p

MOWAC/UNICEF (2009), "Children in Ghana", Ghana: UNICEF.

Ministry of Education (2012), "Education Sector Performance Report (Draft).

Obeng, J. (2005), "Factors which influence pupils' attendance at basic school education. Unpublished master's dissertation", Cape Coast: University of Cape Coast.

Oduro, G. K. T. (2007), "Coping with the challenge of quality basic education: The missing ingredient. In D. E. K. Amenumey (Ed.), Challenges of education in Ghana in the 21 Century, (pp. 229 - 247)", Accra: WOELI PUBLISHING SERVICES

Osei, R. D., Owusu, G., Asem, F. E., \&Afutu-Kotey, R. L. (2009), "Effects of capitation grant on education outcomes in Ghana”, Retrieved July $1, \quad 2011$ from http://depot.gdnet.org/cms/files/GDN_UNDP_ISSER_Paper1.pdf

Sekyere, E. A. (2004), “Teachers' guide on topical issues for promotion and selection interviews (Revised ed.). Kumasi”, AFOSEK Educational Consultancy Center

Sekyere, E. A. (2010), “Teachers' guide on topical issues for promotion and selection interviews (10 th ed.). Kumasi”, AFOSEK Educational Consultancy Center

Sharma, R. N. (2008), “Methodology of educational research”, Delhi: Surjeet Publications.

The Mitchell Group (2009), "Review of basic education quality in Ghana. Basic education in Ghana: Progress and Problems", USAID (Final report)

UNICEF. (2000), "Defining quality in education. A paper presented by UNICEF at the meeting of the International Working Group on Education, document no", UNICEF/PD/ED/00/02. Italy. 